\title{
A LOGISZTIKAI STRATÉGIA ELMÉLETE ÉS LEGFONTOSOBB KÉRDÉSEI
}

A cikkben a szerző áttekinti a logisztikai stratégia alapvető feladatait, a vállalati logisztikai gondolkodást és a stratégiaalkotást támogató legfontosabb modelleket, az irodalomban található logisztikai stratégiai típusokat és a logisztikai képességeket. Megállapítja, hogy a logisztikai képességek kulcsszerepet tölthetnek be a logisztikai és vállalati versenyképességben egyaránt. Ennek ellenére - néhány vállalati eset kivételével - nincs olyan vizsgálat, ami egyértelmű kapcsolatot tudna bemutatni a logisztikai képességek és logisztikai sikeresség, valamint a vállalati versenyképesség között.

A logisztikához kapcsolódó piaci lehetőségek, potenciális versenyelőnyök egyre nagyobb szerepet kapnak a vállalati eredményesség, a versenyképesség javítása, illetve fenntartása szempontjából. A logisztikai stratégia teremti meg azt a kapcsot, amely a vállalati stratégia és a logisztikai funkció összehangolásához szükséges.

A logisztikai stratégia - sem mint fogalom, sem mint a vállalati eszköztár része - nem tekint vissza hosszú múltra. Az elméletben először Heskett munkájában jelent meg (Heskett, 1977), a vállalatok életében azonban jelentősebb szerepet csak a kilencvenes évek óta játszik. A logisztika ${ }^{1}$ maga is csak a hatvanas években válik ismert vállalati fogalommá, mint az a funkció, amely az anyagi folyamatok költségeinek integrált figyelembevételével minimalizálja a feladatának megvalósításához szükséges költségeket. Majd a hetvenes évektől ezt a költségszemléletet egészítette ki a logisztikai szolgáltatási színvonal biztosításának kérdése, de még ekkor is szigorúan operatív, végrehajtó jellegű célrendszerben. A logisztika igazi áttörése, stratégiai szintre emelése, legitimálása a 80-as évekre tehető.

\footnotetext{
A logisztika fogalma jelent egyrészt egy szemléletmódot, melynek középpontjában az anyagi folyamatok és tevékenységek integrációja áll. Másrészt jelenti a logisztika az anyagi jellegú tevékenységek (készletgazdálkodás, szállítás stb.) összességét, harmadrészt pedig jelent egy vállalati funkciót, amely a logisztikai szemléletmód jegyében integrálja a logisztikai jellegű tevékenységeket. Jelen cikkben a logisztika fogalma e vállalati funkciót, illetve a logisztikai jellegű tevékenységek összességét jelenti.
}

Ekkorra a korábban megcélzott versenyelőny-források (költség, minőség) mellett a vállalatok számára egyre fontosabbá válik a kiszállítás megbízhatósága, pontossága, gyorsasága, amelyek jelentős mértékben a logisztika feladatkörébe tartoznak. Ebben az időszakban válik a logisztika a vállalati stratégia részévé, mint potenciális differenciáló tényező (Kent - Flint, 1997).

\section{A logisztikai stratégia fogalma}

A logisztika (mint ahogy valamennyi vállalati funkcionális terület) számára meghatározó kérdés, hogy miként tud (képes-e egyáltalán) a vállalat sikeréhez hozzájárulni. A logisztikai stratégia legfontosabb feladata éppen a stratégia és a logisztika közötti kapcsolat erősítése, koordinálása és irányítása, annak érdekében, hogy a logisztika aktívan hozzájárulhasson a vállalat eredményességéhez, sikerességéhez. A logisztikai stratégiával foglalkozó szerzők munkáiban a fogalom definíciói nagyon közel állnak egymáshoz, inkább csak hangsúlybeli különbségek tapasztalhatók. Wegner szerint a logisztikai stratégia feladata annak vizsgálata, hogy miként járul hozzá a logisztika az üzleti eredményekhez, meghatározza és előírja a logisztikai célokat, és ezekre alapozva logisztikai rendszereket alakít ki (Wegner, 1996). Herter szerint a logisztikai stratégia feladata olyan logisztikai rendszer kialakítása, amely képes versenyelőnyök elérésére (Herter, 2000). E definíciókat felhasználva és kiegé- 
szítve a logisztikai stratégia fogalmát leginkább vállalati feladatával írhatjuk le, mint olyan funkciót, ami koordinációs és integráló szerepet tölt be a logisztika és a vállalati stratégia, a logisztika és az üzletági stratégia, valamint a logisztika és a többi vállalati funkcionális terület között. A vállalati stratégia irányából érkeznek a logisztikával szembeni követelmények, amelyek a szolgáltatási színvonalra és a költségekre vonatkoznak, míg a logisztikai funkció jelzi a lehetőségeket, illetve korlátokat. A logisztikai stratégia pedig a két terület összehangolását végzi. Ha a logisztikai stratégia betölti szerepét, akkor a végeredmény egy olyan logisztikai rendszer lesz, amelyik valóban képes támogatni a vállalati stratégia megvalósulását, miközben a többi vállalati funkcióval is összhangban müködik.

\section{A logisztikai stratégia legfontosabb kérdései}

A logisztikai stratégia alapvető kérdéseinek rendszerezéséhez az 1. ábrán látható struktúrát használjuk. Egy jól működő logisztikai rendszer létrehozásához a következőkre van szükség:

- (1) a szolgáltatási színvonal egyértelmű meghatározása,

- (2) az ellátási lánc struktúrája és a megfelelő hálózati stratégia megtervezése,

- (3) a logisztikai funkciók (szállítás, raktárgazdálkodás, anyaggazdálkodás stb.) megfelelő kialakítása, valamint

\section{A logisztikai stratégia meghatározó elemei}

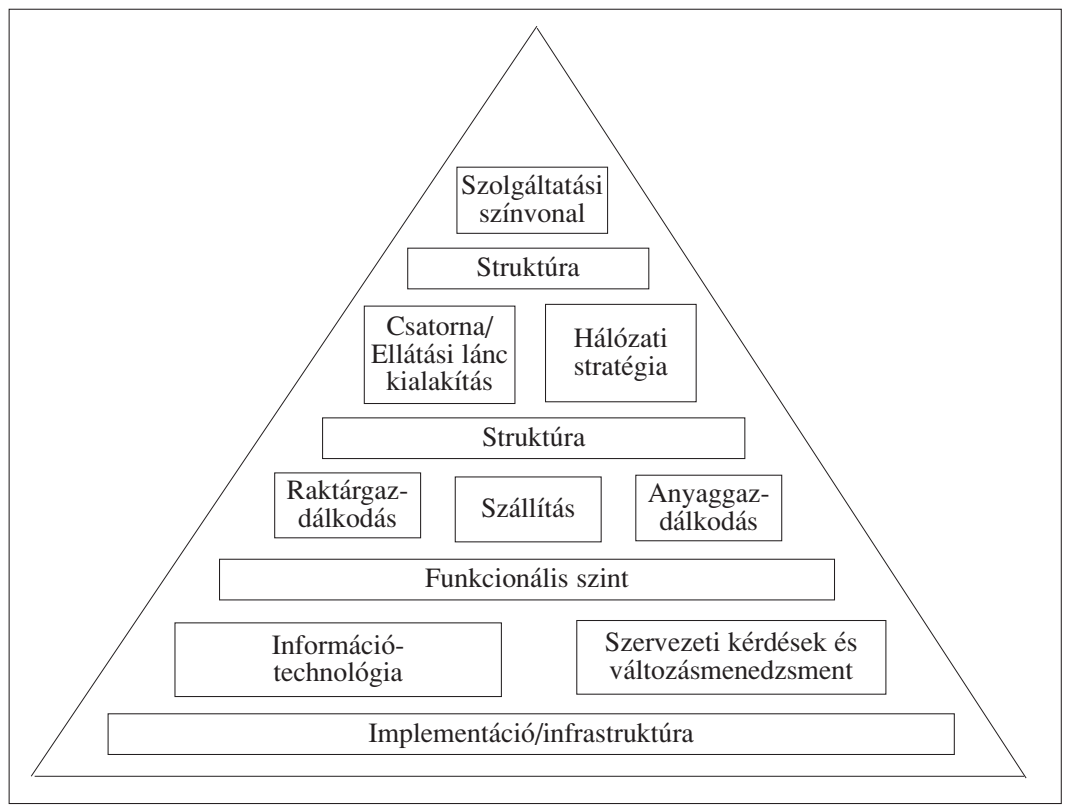

Forrás: O'Laughlin-Copacino (1994), Stock-Lambert (2001)
- (4) megfelelő információs technológia, döntési és működési mechanizmusok, hatékony szervezet és változásmenedzsment.

Mindemellett ezen elemek teljes összehangolása és koordinálása szükséges (O'Laughlin - Copacino, 1994; Stock - Lambert, 2001). Az 1. ábra piramisa az előbb említett négy problématerületet különböző szintekre helyezi, ezzel is segítve a logisztikai rendszer strukturált átgondolásának és kialakításának lehetőségét. A piramis mind a vállalaton belüli logisztika, mind teljes ellátási láncok esetén jó kiindulást jelent a logisztika megtervezéséhez.

A kialakítás nem jelent hierarchiát is egyben, nem feltétlenül fentről lefelé történik a tervezés. Sokkal inkább egyfajta ellenőrző listát nyújt ahhoz, hogy a logisztikai rendszer kialakításakor mely kérdéseket kell figyelembe venni. A nehézséget pontosan az okozza, hogy itt különböző dimenzióban megjelenő kérdéskörök összhangját kell megteremteni. Ettől érdekes és nehéz, kihívásokkal teli, sokféle emberi képességet (technikai és gazdasági ismereteket, elemzési készséget) igénylő feladat a logisztikai stratégia, és a teljes logisztikai rendszer átfogó kialakítása. Fontos, hogy a felsorolt kérdések folyamatosan nyitottak legyenek a vállalati menedzsment számára, ugyanis a változó környezetben - ahol az új technológiák és módszerek a lehetőségeket, és az erőforrások költségeinek arányait folyamatosan változtatják - állandó odafigyelést és elemzést igényelnek. ${ }^{2}$

\section{Stratégiai döntések}

1. ábra A legfelső stratégiai szinten található az a döntés, hogy a logisztikai szolgáltatási színvonal mely dimenzióira koncentráljon a vállalat, és azon belül milyen célértékeket határozzon meg. A kérdés megválaszolásához egyrészt a meglevő logisztikai rendszer és a logisztikai képességek, valamint a fogyasztói igények megfelelő ismerete szükséges. Ezeken túlmenően a szolgáltatási színvonalnak összhangban kell lennie a vállalati célokkal, így a vállalati stratégiával, valamint a marketingstratégiával. Ha több vállalatot átfogó rendszerben (ellátási láncokban) gondolkodunk, akkor az előbbiek mellett össze kell hangolni a megcélzott szolgáltatási színvonalat a teljes láncolatra kiterjedő, közös célrendszerrel is.

A termelési stratégiában Terry Hill készített hasonló modellt (Hill, 1995), ő azonban a rendszerébe közvetlenül beemelte a vállalati stratégiai célokat és a marketingstratégia elemeit. 
Természetesen egy többtermékes vállalat esetében az egyes termékekre vonatkozó szolgáltatási színvonal célok eltérhetnek, ennek következtében a logisztika differenciált és komplex kihívásokkal szembesülhet.

Ha a termék magas szintű elérhetősége jelenti a versenykritériumot a vállalat vagy az üzletág készletre fog termelni. A szolgáltatási színvonal kulcsdimenziója a rendelkezésre állás lesz. A logisztika ennek megfelelően a készletezésre és a raktárgazdálkodásra fog koncentrálni. Ha a termék készletezése túl nagy kockázatot jelent, a vállalat nem fog készletet tartani, hanem rendelésre fog gyártani. Ekkor a gyors átfutási idő, a pontos szállítás jelentheti a sikerkritériumot, a logisztikai és termelési kapacitások rendelkezésre állására fognak törekedni a struktúra kialakításakor. A logisztikai rendszer a szállításra fog koncentrálni. Készletekre természetesen itt is szükség van, de azok alacsonyabb feldolgozottsági szinten, az ellátási lánc megelőző fázisaiban állnak rendelkezésre.

\section{Strukturális döntések}

A logisztikai stratégia egyik meghatározó kérdése, hogy milyen logisztikai struktúrát alakítunk ki vállalati és abból származtatott logisztikai céljaink elérésének támogatására. A struktúra kérdésköre kettős, a csatorna kialakítása az ellátási lánc menti munkamegosztást, a hálózat az ellátási lánc menti fizikai struktúrákat (raktárak helye, száma, készletek helye, szállítási útvonalak stb.) jelenti. A piramis második, strukturális szintjén a logisztikai struktúra kialakításának kérdései találhatók. A vállalatnak át kell gondolnia, hogy a fogyasztók ellátásához mely tevékenységekre van szüksége, a tevékenységek milyen formában kapcsolódjanak össze, milyen struktúrájú legyen az ellátási lánc. Továbbá meg kell határoznia, hogy a termék mely csatornákon, mely vállalatok hozzájárulásával készüljön el és jusson el a fogyasztóhoz, illetve a szükséges tevékenységeket hogyan lehet optimális módon a résztvevő vállalatok között megosztani (például „venni vagy gyártani” típusú kérdések). Ugyanakkor itt kell meghatározni azt is, hogy ténylegesen milyen fizikai struktúrák igénybevételével (létesítmények száma, elhelyezése, mérete) valósíthatók meg a szükséges tevékenységek: itt kell többek közt meghatározni a szállítási módokat és azt, hogy a szállítások merre haladjanak, hol legyenek a készletek. A két kérdés szorosan összefügg, kölcsönösen és folyamatosan hatnak egymásra, egyiket sem lehet hatékonyan megválaszolni a másik megválaszolása nélkül. Ha módosul az ellátási lánc menti partneri kör, az természetszerűleg módosíthatja a készletezési helyeket, a szállítási útvona- lakat egyaránt. A strukturális döntések meghozatalának a szükséges szolgáltatási színvonal mellett mindenesetre átfogó költségmegfontolásokat is tartalmaznia kell a logisztikai teljes költség koncepció jegyében.

\section{A csatorna kialakítása}

A csatorna kialakítása azzal kezdődik, hogy el kell dönteni, hogy milyen tevékenységeket kell az adott szolgáltatási színvonal eléréséhez elvégezni. Ha már tudjuk, hogy mely tevékenységeket szeretnénk elvégezni, meg kell határozni, hogy ezeket a tevékenységeket a csatorna mely szereplőjére bízzuk, mely tevékenységeket végezzen adott vállalat maga, és mely tevékenységek kerüljenek más vállalatokhoz. Ennek eredményeként megkapjuk a csatorna szereplőinek számát, összetételét, valamint azt, hogy a vállalat maga mekkora részt vállal a végső szolgáltatás vagy termék előállításában, mekkora lesz a saját hozzáadott értéke.

$\mathrm{Az}$ ellátási lánc az alapanyagforrásoktól a végső fogyasztásig terjedő anyagáramlást öleli át. Napjaink vállalatai számára az egyik meghatározó kérdés, hogy miként tudják a fogyasztók ellátásához szükséges tevékenységláncolatot kézben tartani. Az ellátásiláncmenedzsment integrálja az ellátási lánc tevékenységeit a végső felhasználó igényeinek versenyképes kielégítése céljából. Ezek a tevékenységek azonban a legritkább esetben zajlanak egyetlen vállalat keretein belül, gyakran nagyobb számú vállalat járul hozzá ahhoz, hogy adott nyersanyagoktól kiindulva megtörténjen a végső felhasználó igényeinek kielégítése. Az ellátási lánc menedzsmentjének egyik legfontosabb jellemzője, hogy az ellátási lánc menti feladatok integrációja úgy valósul meg, hogy közben nincs szükség ezen feladatok elvégzését biztosító vállalatok közös tulajdonlására. Ennek az integrációnak a bázisa egyrészt az információ-technológia, másrészt a vállalatok közötti bizalom (Cooper - Lambert - Pagh, 1997; Mentzer et al., 2001).

$\mathrm{Az}$ elmélet középpontjában az a felismerés áll, hogy a végső felhasználó számára nyújtott szolgáltatási színvonalhoz hozzájárulnak mind az adott vállalat tevékenységei, mind az azt megelőző és az utána következő tevékenységek. Tehát, ha a vállalat versenyképessé akar válni, vagy versenyképes akar maradni, foglalkoznia kell a beszállítók és a vevők tevékenységével is. Alapvetően két dolog indokolja, hogy a vállalatok számára az eddigi önálló vállalatban való gondolkodásuk helyébe a teljes ellátási láncban való gondolkodás lépjen. Első ilyen érv a verseny fokozódása. Miután pedig a karcsúsított termelés jegyében átszervezett belső vállalati folyamatok további fejlesztési potenciálja leszűkült, a hatékonyságjavítás terepe 
bizonyos mértékig a vállalaton kívülre, a teljes ellátási lánc menti munkamegosztás újragondolására helyeződött át. A másik ok a lehetőségek kibővülése, az információs technológiák tömeges elérhetősége. Az információs technológiára alapozva a többi vállalatra vonatkozó információ is valós időben elérhető, ami növeli a bizalmat, és növeli a döntések átláthatóságát. Az ellátási láncban való gondolkodás egyes esetekben vezethet a partnerek cseréjéhez, vagy az egyes tevékenységek vállalatok közötti átcsoportosítására az ellátási láncon belül, vagy vezethet ahhoz, hogy a vállalatok közé új szolgáltató vállalatok épülnek be bizonyos tevékenységek kiszervezése, outsourcingja eredményeként. Outsourcing esetén a vállalat korábban maga által végzett, stratégiailag fontos tevékenységeket vállalaton kívülre helyezi, de azzal továbbra is szoros kapcsolatot tart fenn. A vállalat az adott tevékenység konkrét végzésétől megszabadul ugyan, de ezzel együtt a tevékenység feletti kontrollja megmarad. Az outsourcing esetén tehát mindenképp változik a csatorna menti munkamegosztás, és adott esetben, az új vállalat keretein belül változhat maga a végrehajtott tevékenység is (Gritsch, 2003; Wimmer, 2003).

A csatorna kialakítását a szolgáltatási színvonal kérdésén kívül is számos tényező befolyásolja, például a vállalat relatív alkupozíciója a partnerekkel szemben, vagy az adott tevékenységet végzők száma, versenyhelyzete. A csatorna kialakítását célszerű jól átgondoltan végrehajtani, ugyanis sokszor hosszabb távú elkötelezettség mellett lehet megtenni, amelynek korrigálása nehéz és költséges lehet.

\section{Hálózati stratégia}

A hálózati stratégia meghatározó kérdése, hogy a termék vagy szolgáltatás milyen fizikai infrastruktúrán keresztül jusson el a fogyasztóhoz, milyen infrastruktúra képes egyáltalán a leghatékonyabban biztosítani az elvárt szolgáltatási színvonalat. Ennek során további kérdéseket kell feltenni a logisztikai hálózat paramétereire (pl. centralizáció mértéke, mely funkciók legyenek centralizáltak stb.), valamint a logisztikai hálózat létesítményeire vonatkozóan:

- Hány létesítményre van szükség az elvárt szolgáltatási színvonal hatékony biztosításához?

- Hol legyenek a létesítmények, és azok milyen funkciókkal rendelkezzenek? Adott raktárépület például hogyan legyen elérhető, rendelkezzen-e iparvágánynyal, vagy megfelelő vízi kapcsolattal? Mennyi készlet tárolására legyen alkalmas, naponta mekkora mennyiséget lehessen komissiózni és kiszállítani? Lehessen-e benne a raktározáson kívül egyéb tevékenységeket is végezni? Legyen-e alkalmas például cross docking funkciók ellátására?
A hálózati stratégiák fontos kérdése továbbá, hogy hol legyenek a készletek. A kérdést két oldalról is meg lehet közelíteni. A hatalmi logika szerint a gyengébb láncszem fogja a készletezés terheit viselni cserébe azért, hogy egyáltalán tagja lehet a láncnak (Chikán, 1995). Ez figyelhető meg a JIT beszállítások területén: az erős autóipari cégek gyenge alkuerővel rendelkező beszállítói kénytelenek a készleteket tartani, ráadásul a partner számára megfelelő időben szállítani. A munkamegosztás alapját jelentheti a racionalitás is: a vállalatok megpróbálják megtalálni az üzleti logikának (kereslet, átfutási idő stb.) leginkább megfelelő készletezési pontot a láncon belül (ekkor a készleteket tartó vállalat még kompenzációra is számíthat a pótlólagos teljesítmények, illetve költségek miatt). Az elmúlt években az ellátási láncok készletezése kapcsán ez a problémakör a késleltetés vs. spekuláció kérdéseként került a figyelem középpontjába (Gelei, 2003).

\section{Funkcionális döntések}

Adott struktúra önmagában azonban nem biztosítja a hatékony múködést. A tervezett struktúrához hozzá kell rendelni a tényleges logisztikai funkciókat, a szállítást, a készletezést, a raktározást, anyaggazdálkodást. Ez a harmadik, funkcionális szint. A kérdések az egyes funkciók tényleges működését fogják meghatározni. Milyen anyaggazdálkodási, illetve készletezési logika tudja támogatni a meghatározott szolgáltatási színvonalra vonatkozó célokat, hogyan működjön a raktározás (raktározási mód, technológia stb.)? Itt kell eldönteni például, hogy a készletezést milyen logikával, milyen készletezési mechanizmusra alapozzuk, milyen módon tartjuk nyilván a készleteket, hogyan értékeljük azokat? Hogyan optimalizálható például a szállítási funkció, hogyan tervezhetők hatékonyabban szállítási útvonalak, csökkenthetőek-e adott esetben a szállítási költségek például a szállítóeszköz jobb kiválasztásával? Az egyes funkciók közötti költségátváltások miatt azonban nem lehet egyes funkciókat önmagukban optimalizálni, mindig figyelembe kell venni a teljes költség koncepció jegyében a többi funkciónál bekövetkező változásokat is.

Az egyes logisztikai struktúrák a logisztikához kapcsolódó funkciókat különböző arányokban veszik igénybe. Mások lesznek a tevékenységek, ha a vállalat a fogyasztó közvetlen ellátását választja például egy webáruházon keresztül, és mások, ha valamilyen többlépcsős disztribúciós csatornát választ a disztribúciós tevékenysége során, de akár kombinálhatja is a különböző megoldásokat. Az első esetben például a vállalat maga készletezhet, és készletről szállíthat a webáruház megrendelőinek, míg a másik esetben a készletezési és 
raktározási tevékenység valószínúleg valamelyik partnercéghez kerül át. Nyilvánvaló itt az iparág és az elvárt szolgáltatási színvonal meghatározó szerepe. Egy kiskereskedelmi vállalat esetében például a készleteknek - vagyis annak, hogy van-e termék a polcokon - meghatározó a jelentősége. Ezzel szemben egy autógyárban meghatározó kérdés, hogy mindig legyen alapanyag - készletről, vagy éppen időben beszállítva.

\section{Infrastrukturális/implementációs döntések}

Végezetül az előbbi szintek kérdéseihez kell illeszteni a támogató eszköztárat: az operatív múködés szabályrendszereit, a kapcsolódó szervezeti struktúrát, az információs rendszereket, a kontrollmechanizmusokat, a teljesítménymérést. Ez a logisztikai piramis negyedik, infrastrukturális szintje.

Megfelelő információs rendszer támogatása nélkül ma már nem lehet hatékony logisztikai rendszert kialakítani. Az információs rendszer támogatja szinte az összes vállalati folyamatot a beszerzéstől az értékesítésig, és a vállalati határokon túlmenően is. Támogatja többek között a tervezési folyamatokat, a kapacitástervezést, a rendelési folyamatokat, a készletgazdálkodást, a szállítás optimalizálását.

Az integrált logisztikai rendszer kialakítása nem jelenti feltétlenül azt, hogy egy centralizált logisztikai szervezetben fogjuk össze a logisztikai tevékenységeket, a készletgazdálkodástól a szállításig. Vannak vállalatok, amelyek a beszerzési-termelésellátási oldalt és az értékesítési oldalt logisztikai szempontból különválasztják, mert a két rész meglehetősen jól elkülönül. Másoknál valamennyi anyagi folyamatot integrálják, a termelést is beleértve. Az, hogy mely logisztikai tevékenységek kerülnek egy szervezeti egység felügyelete alá, természetesen függ a vállalat hagyományaitól, méretétől (a logisztikának az alapja is sok esetben egyfajta méretgazdaságosság), vagy éppen a piaci verseny intenzitásától. Nem a tevékenységek szervezeti összefogása azonban a lényeg, hanem a logisztikai tevékenységek tényleges összehangolása. A logisztikai tevékenységek integrációjának együttes szemléletként kell megjelennie a szervezetben. Ehhez felelős személyekre, azok valamilyen szervezeti elhelyezésére és kapcsolódó teljesítményértékelésre van szükség. A logisztikai integrációért felelős személyek elhelyezkedhetnek egy ténylegesen logisztikának nevezett szervezeti egységben, de akár a termeléshez, vagy éppen a marketinghez kapcsolódóan is. Ténylegesen nem az a meghatározó kérdés, hogy a logisztika milyen szervezeti keretben helyezkedik el, hanem az, hogy a logisztika alapgondolata, az anyagi tevékenységek integrációja megvalósul-e, bármilyen szervezeti egység keretében.

\section{A logisztikai stratégia tervezésének folyamata}

A logisztikai stratégia tartalmi kérdései után a logisztikai stratégia tervezésének folyamatát vizsgáljuk. (1) Ennek első lépéseként a vállalati stratégia, a fogyasztói igények, valamint egyéb külső tényezők figyelembevételével valamilyen vizió kialakitására van szükség. Ez azért is lényeges, mivel egy ilyen előzetes tervezési fázisban felmerülhetnek új ötletek, figyelembe lehet venni olyan lehetőségeket, új technológiákat, amelyek közvetlenül a struktúra kialakításakor esetleg már nem illeszkedhetnének be a logisztikai rendszerbe. Ha adott esetben felmerül egy új technológia (pl. rádiófrekvenciás termékazonosítás és nyomon követés, RFID) alkalmazásának lehetősége, akkor ez nyilvánvalóan hatással lesz az előbb bemutatott piramis több elemére is, amely hatásokat a tervezés már korai szakaszában meg kell vizsgálni. Lehet, hogy a megoldás túl költséges, vagy nem felel meg a jogi követelményeknek, vagy egyszerűen a vállalatvezetés támogatását nem élvezi. De elképzelhető, hogy olyan új megoldások, javaslatok születnek, amelyek alapjaiban változtatják meg a vállalat működését is. (2) Ha megállapodás született a fő irányokról, az alkalmazandó technológiákról, akkor a korábban bemutatott logisztikai piramisra építve átfogó stratégiai elemzést kell végezni, hogy az egyes elemek között ne legyenek konfliktusok, a logisztikai rendszer valóban a vállalati stratégia érdekeit szolgálja. (3) Ha tudja a vállalat, hogy milyen logisztikai rendszert akar megvalósítani, akkor meg kell határozni a szükséges lépéssorozatot, programokat célokkal, felelősökkel, amelyek ténylegesen elvezetnek a logisztikai stratégiában megtervezett rendszerhez. Természetesen az előbb felvázolt három elem között folyamatos visszacsatolást kell biztosítani. Elképzelhető, hogy a programok tervezésének eredményeként is még módosítani kell a vizionálási fázis outputjait, iteratívvá téve az egész folyamatot. Végezetül következhet a változások vállalati vagy az ellátási lánc egészére kiterjedő megvalósításának szakasza (O'Laughlin - Copacino, 1994).

\section{Vállalati logisztikai stratégiák, csoportosításuk}

A vállalatok által követett logisztikai stratégiák azonosításával több szerző is foglalkozott, de empirikusan is alátámasztott, stabil kategóriarendszer kevés van. Az egyik legelső munkában Shapiro és Heskett három potenciális logisztikai versenystratégiát különböztet meg: az innovációs stratégiát, a szolgáltatási színvonalra alapozott stratégiát, valamint a költségvezető stratégiát. E differenciálás azonban később nem 
kapott empirikus megerősítést (Shapiro - Heskett, 1985). Egy általánosan elfogadott, és empirikusan is ellenőrzött megközelítés Porter generikus stratégiáit (Porter, 1980) alkalmazza a logisztika területére. Bowersox és Daugherty a költségvezető stratégia helyébe a költségminimalizáló stratégia fogalmát helyezi, a differenciálást a hozzáadott érték maximalizálás váltja, míg a fókuszálás helyébe a kontrollt és alkalmazkodóképességet középpontba helyező logisztikai stratégia lép (Bowersox - Daugherty, 1995). Ezeket a stratégiákat mutatjuk be részletesebben.

\section{A költségminimalizáló \\ logisztikai stratégia}

E stratégia erősen árérzékeny piaci szegmensek ellátása esetén alkalmazott. Ilyenkor is szükséges azonban a szolgáltatási színvonal területén egy iparági minimális színvonal elérése. A vállalat legfontosabb teljesítménycélja a belső hatékonyság elérése. Ehhez szükséges a költségek szigorú kontrollja, illetve a tevékenységek méretgazdaságos ellátása. Az ilyen vállalat külső kapcsolataiban az egyes tranzakciókra koncentrál, a vásárlások meghatározó tényezője az ár, amit például nagyszámú beszállító versenyeztetésével érhetnek el (1. táblázat).

1. táblázat

\section{Költségminimalizáló stratégia}

\begin{tabular}{|l|l|}
\hline Stratégiai orientáció & \multicolumn{1}{|c|}{ KöLTSÉGMINIMALIZÁLÁs } \\
\hline Teljesítménycél & Belső hatékonyság \\
\hline $\begin{array}{l}\text { Hagyományos } \\
\text { struktúra/belső }\end{array}$ & $\begin{array}{l}\text { A költségek szigorú kontrollja. Output- } \\
\text { maximalizálás, méretgazdaságosság. }\end{array}$ \\
\hline $\begin{array}{l}\text { Hagyományos } \\
\text { struktúra/külső }\end{array}$ & $\begin{array}{l}\text { Tranzakció-orientált. Ár alapú vásárlás, } \\
\text { sok beszállítóval. }\end{array}$ \\
\hline
\end{tabular}

\section{Hozzáadott érték maximalizáló logisztikai stratégia}

E stratégia kulcsa annak megállapítása, hogy a piac mely termék, illetve szolgáltatási jellemzőket értékeli leginkább. Ha a vállalat képes szolgáltatásait a versenytársaktól megfelelően megkülönböztetni, akkor számíthat az egyediségre alapozott piaci árprémium elérésére. E stratégia középpontjába a külső hatékonyság elérése kerül, aminek belső strukturális feltétele a folyamatok integrációja. A beszállítók kiválasztásának alapja a kiszolgálás minősége, fontos az állandó rendelkezésre állás, a rugalmasság és a minőség folyamatos fejlesztése (2. táblázat).

\section{Kontrollra és alkalmazkodóképességre épülo" stratégia}

Ebben az esetben cél egy jól meghatározott szegmens vagy vásárlói csoport kielégítése, amihez nagymértékủ rugalmasság szükséges. E rugalmasság alapja a tevékenységek erős kontrollja például vertikális integrációra alapozva. A külső partnerek választása gyakran azon alapul, hogy az rendelkezik-e azokkal a képességekkel, amelyek egyediek és specializáltak és nem érhetőek el vállalaton belül. Ezeket a vállalatokat jellemzi az erôs innovativitás, valamint a döntési felelősség nagymértékű delegálása (3. táblázat).

2. táblázat

Hozzáadott érték maximalizáló stratégia

\begin{tabular}{|l|l|}
\hline Stratégiai orientáció & HOZZÁADOTT ÉRTÉK MAXIMALIZÁLÁs \\
\hline Teljesítménycél & Külső hatékonyság \\
\hline $\begin{array}{l}\text { Hagyományos } \\
\text { struktúra/belső }\end{array}$ & $\begin{array}{l}\text { A folyamat integrációja minőség/meg- } \\
\text { különböztetés céljából. }\end{array}$ \\
\hline $\begin{array}{l}\text { Hagyományos } \\
\text { struktúra/külső }\end{array}$ & $\begin{array}{l}\text { Kapcsolat alapú csere. Szervezeti hatá- } \\
\text { rokat áttörő kapcsolatok. }\end{array}$ \\
\hline
\end{tabular}

3. táblázat

Kontrollra és alkalmazkodóképességre épülő stratégia

\begin{tabular}{|l|l|}
\hline Stratégiai orientáció & KONTROLL/ ALKALMAZKODÓKÉPESSÉG \\
\hline Teljesítménycél & Rugalmasság \\
\hline $\begin{array}{l}\text { Hagyományos } \\
\text { struktúra/belső }\end{array}$ & $\begin{array}{l}\text { A rugalmasság és reagálóképesség } \\
\text { maximalizálása. }\end{array}$ \\
\hline $\begin{array}{l}\text { Hagyományos } \\
\text { struktúra/külső }\end{array}$ & $\begin{array}{l}\text { Erős vállalatközi szövetségek, ,méret- } \\
\text { reszabás”. Szoros koordináció. }\end{array}$ \\
\hline
\end{tabular}

Bowersox és Daugherty egy korábbi munkájában (Bowersox - Daugherty, 1987) a logisztikai stratégia és a szervezeti struktúra elemzése alapján három logisztikai stratégiát különböztettek meg: (1) a folyamat-, (2) a piac- és (3) az információközpontú stratégiákat. E harmadikat későbbi munkáikban csatornaközpontú stratégiának nevezik. Ezeket azonban nem tartják abszolút kategóriáknak, adott vállalatoknál is keveredhetnek. A folyamatközpontú stratégiát követő vállalatok nagyszámú logisztikai tevékenységet végeznek, törekedve azok integrálására és a költségelőnyök (belső hatékonyság) elérésére. A piacorientált vállalat kisszámú logisztikai tevékenység integrálására törekszik a piaci jelenlét egységesítése érdekében. (Például különböző termékek közös szállítása egyazon fogyasztóhoz.) Ezzel szemben a csatornaközpontú stratégia alapja, hogy a vállalat az ellátási lánc mentén szoros kapcsolatra törekszik az egyes szereplők között, aminek eredménye lehet a készletezési pontok eltolódása a lánc mentén. Több vizsgálat is ismert, amelyek e stratégiák létét, valamint e tipizálás statisztikai erősségét tesztelik. Ezek szerint sok ugyan az átfedés és hasonlóság az egyes kategóriák vállalatai között, de a súlypontokban komoly eltérések mutatkoznak (McGinnis - Kohn, 1990; Clinton - Closs, 1997). Későbbi vizsgálatok azt mutatják, hogy a vállalatok leggyakrabban folyamatorientált stratégiát követnek 
(kb. 60\%), egy kisebb részük piacorientált (kb. 30\%), míg a csatornaorientált stratégiára nagyon kevés (10\% körüli) példát találtak. McGinnis és Kohn (1993) e tipológiából kiindulva arra a következtetésre jut, hogy ha a kevésbé elterjedt csatornaorientált stratégiát kihagyják a vizsgálatból, a vállalatok három jól elkülöníthető csoportba sorolhatóak. Az első csoport vállalatai intenziv logisztikai stratégiát folytatva erôs hangsúlyt fektetnek mind a piacalapú, mind a folyamatalapú logisztikai stratégia elemeire. Ez a vállalati csoport tevékenykedett a legintenzívebb versenykörnyezetben. A kiegyensúlyozott stratégiát követők (a vizsgált vállalatok nagy része, mintegy 61 százaléka) mindkét alapstratégiára hangsúlyt fektettek, de nem olyan mértékben, mint az első csoport. A nem fókuszált stratégia vállalatai egyik stratégiát sem követték kellő elkötelezettséggel, kis hangsúlyt fektettek a szolgáltatási színvonalra és egyéb logisztikai tényezőkre. E harmadik stratégia kevésbé intenzív versenykörnyezetben tevékenykedő vállalatokra volt jellemző. A szerzők következtetése, hogy a környezet, azon belül is a verseny intenzitása alapvetően határozza meg a vállalat logisztikai stratégiáját.

Az eddigi kategorizálásokhoz hasonlóan a logisztikai stratégia tartalmi részére koncentrál Persson (1991) is, de szempontrendszere eltér az eddigiektől. Ő is három logisztikai stratégiai kategóriát javasol. Az első kategória vállalatai a logisztikát a versenytényezők befolyásolásával versenyelőnyök kialakítására használják. A második kategória vállalatai a logisztikát új üzleti területek, új logisztikai szolgáltatások kialakítására használják, míg a harmadik kategóriában a vállalatok új megoldásokkal és rendszerek kombinálásával magasabb szintű logisztikai szolgáltatások kialakítására törekednek. Persson kategóriarendszerét a logisztikai irodalomban később nem tesztelték, valószínúleg a kategóriák nehéz elkülöníthetősége, illetve mérhetősége miatt.

A logisztikai stratégia három alapformáját különbözteti meg Herter (2000) is. A költségvezető, a minőségvezető, valamint az idővezető stratégiák mindegyike a vállalat versenyelőny forrásain alapul. Amerikai és német vállalatokat összehasonlító empirikus elemzése során azt tapasztalta, hogy a vállalatok 6 százaléka porteri értelemben költségvezető, 78,5 százaléka differenciáló, 15,5 százaléka pedig vegyes stratégiát követ. A logisztikai stratégiákban minőségvezető volt a vállalatok nagy része $(49,4 \%)$, költségvezető 31,4 százalék, míg idővezető 19,2 százalék. A két adatsor nem teljesen konzisztens, a legnagyobb eltérés a költségek vonatkozásában tapasztalható, a vállalatok 6 százalékos értéke a logisztika esetében már 31 száza- lék. Ezek az adatok arra utalnak, hogy a logisztika legitimációja máig nem teljes, sok helyen tapasztaljuk, hogy a logisztika végrehajtó jellegü tevékenységként a költségek minimalizálását kapja feladatul.

\section{A sikeres logisztika meghatározó tényezői - a logisztikai képességek vizsgálata}

Az üzleti tudományokban egyre gyakrabban találkozhatunk olyan felmérésekkel, amelyek a vállalati siker kritériumainak meghatározására törekednek. A logisztika területén is több ilyen felméréssel találkozhatunk, amelyek eredményei erősen korrelálnak, inkább csak hangsúlybeli különbségek tapasztalhatók. A sikertényezők száma változó, de a következő öt logisztikai sikertényezőt szinte minden felmérés kiemeli (Bowersox - Daugherty, 1992; Pfohl - Large, 1994; Kummer, 1999): a logisztikai feladatok átfogó megszervezését, a logisztikai tevékenységek bekapcsolását a vállalati tervezésbe, logisztikai partneri viszonyok kiépítését, az új információs és kommunikációs technikák intenzív használatát és a hatékony logisztikai kontrollingot (Bowersox - Daugherty, 1992). Ha e tényezőket összevetjük a hazai helyzetet jól tükröző „Versenyben a világgal” eredményeivel azt tapasztaljuk, hogy a hazai vállalatok az új információs és kommunikációs technikák használatán kívül egyik sikertényezőben sem jeleskednek. Nem jellemző a logisztikai feladatok átfogó megszervezése, a logisztika még kevésbé integrált tevékenységet jelent. Nem jellemző a logisztika bekapcsolódása a vállalati tervezésbe, inkább az operatív, végrehajtó jelleg dominál. Ennek megfelelően alakul a logisztikai kontrolling feladatköre is, inkább az operatív, költségalapú mérôszámok a jellemzőek. Nem meghatározóak a hosszú távú partneri kapcsolatok sem (Gelei, 1997; Gelei, 2005).

$\mathrm{Az}$ elmúlt évtizedben a vállalati stratégia irodalmában jelentős teret kapott az erőforrás-alapú stratégiaszemlélet (pl. Prahalad - Hamel, 1994). A logisztikai képességek a vállalat számára alapvető képességek lehetnek, olyan képességek, amelyek ritkák, értékesek és nehezen másolhatók, érdemes lehet tehát rájuk alapozva kialakítani a vállalati stratégiát is (Olavarrieta Ellinger, 1997). Több szerző szerint a logisztikához kapcsolódó képességek, például gyors, pontos kiszállítás nélkül nem is lehet a vállalat eredményes. Vállalati példák azonban ez utóbbi állítást cáfolják, vagyis vannak olyan, kiválóan működő vállalatok, amelyek logisztikája számos problémát mutat, ugyanakkor számos olyan példa is van, ahol a logisztika valóban a vállalati siker kulcstényezőjévé vált (többek közt a Dell példáját, Magretta, 1998). 
Egy nagyszabású felmérésben a Michigan State University kutatói arra a kérdésre keresték a választ, hogy melyek a legfontosabb logisztikai képességek, a sikeres logisztikával rendelkező vállalatokat mi jellemzi, milyen képességekkel rendelkeznek. A Council of Logistics Management (CLM) támogatásával elvégzett felmérésben 3693 amerikai, ázsiai és európai vállalatot vizsgáltak kérdőíves felmérésre alapozva. A megkérdezett vállalatok közül előzetes szempontok és megkérdezések alapján kiválasztottak 111 világszínvonalú logisztikával rendelkező vállalatot, amelyeknél interjúkat is készítettek. A kutatás során e két vállalati csoportot hasonlították össze, és arra kerestek választ, hogy melyek azok a logisztikai képességek, melyek kiváló logisztikai teljesítményekhez vezetnek, hozzájárulva egyben a vállalat sikerességéhez. Négy olyan képességcsoportot, ezen belül 17 olyan képességet határoztak meg, amelyek szükségesek a logisztika sikerességéhez: a pozícionálás, az integráció, az agilitás és a teljesítménymérés képességét (2. ábra). Azt állapították meg, hogy azok a vállalatok, amelyek kiváló logisztikával rendelkeznek, mindegyike rendelkezik ezen a meghatározott négy területen a megfelelő képességekkel, illetve összességében ezeken a területeken legnagyobb a különbség teljesítményük és a többi vállalat teljesítménye között (CLM, 1995).

1. Pozícionálás. A kiváló logisztikával rendelkező vállalatok esetében a többieknél sokkal inkább stratégiai jelentőséggel rendelkezik a logisztika. Ennek megfelelően ezek a vállalatok rendelkeztek a megfelelő gyakorlattal és eszköztárral a logisztikai stratégia kialakításához, összességében képesek voltak megfelelő logisztikai stratégia, illetve struktúra kialakítására. A kiemelt vállalatok képes- nek mutatkoztak a logisztikai stratégiai fókuszok meghatározására, a megfelelő szolgáltatási színvonal-dimenziók meghatározására. Sokkal több figyelmet fordítottak a vállalati funkciók összehangolására, többek közt a marketinggel és a termeléssel való koordinált együttmúködésre. Jellemezte őket a centralizáció és decentralizáció közötti kényes egyensúly megteremtése, az ellátási láncaik menedzsmentjének gyakorlata, a folyamatokban való gondolkodás, a globális beszerzés gyakorlata, valamint az információáramlás szinkronizálása.

2. Integráció. A logisztika hatékony múködésének egyik feltétele a külső és belső integráció megteremtése. A kiváló logisztikával rendelkezők ezen a területen is fejlettebb képességekkel bírtak, mint az átlagos vállalatok. Az integrációs képességek alapját jelentik mindenképpen a technológiai és információtechnológiai ismeretek és képességek, a rendszerintegrációs képességek, az EDI és a vonalkódos rendszerek használata. Az integrációs képességek kiterjednek a rendszer elemei, az egyes vállalatok, az egyes funkcionális területek közötti információ megfelelő megosztására, ami a bizonytalanság, a kockázatok csökkentéséhez vezet mind vállalaton belül, mind a vállalatok között. Kiterjednek továbbá a rendszer elemeinek összekapcsolhatóságára, vagyis a megfelelő időn belüli információcsere képességére. Az integráció jelent ezeken kívül standardizációt is, vagyis az információk azonos formátumát, a tevékenységek konzisztenciáját. Az integráció egyik feltétele továbbá a struktúrák egyszerűsítése, ami kiterjed a belső hálózatokra, valamint a külső ellátási láncok komplexitásának (pl. beszállítok számának) csökkentésére, a modularizálásra.

2. ábra

\section{Logisztikai képességek}

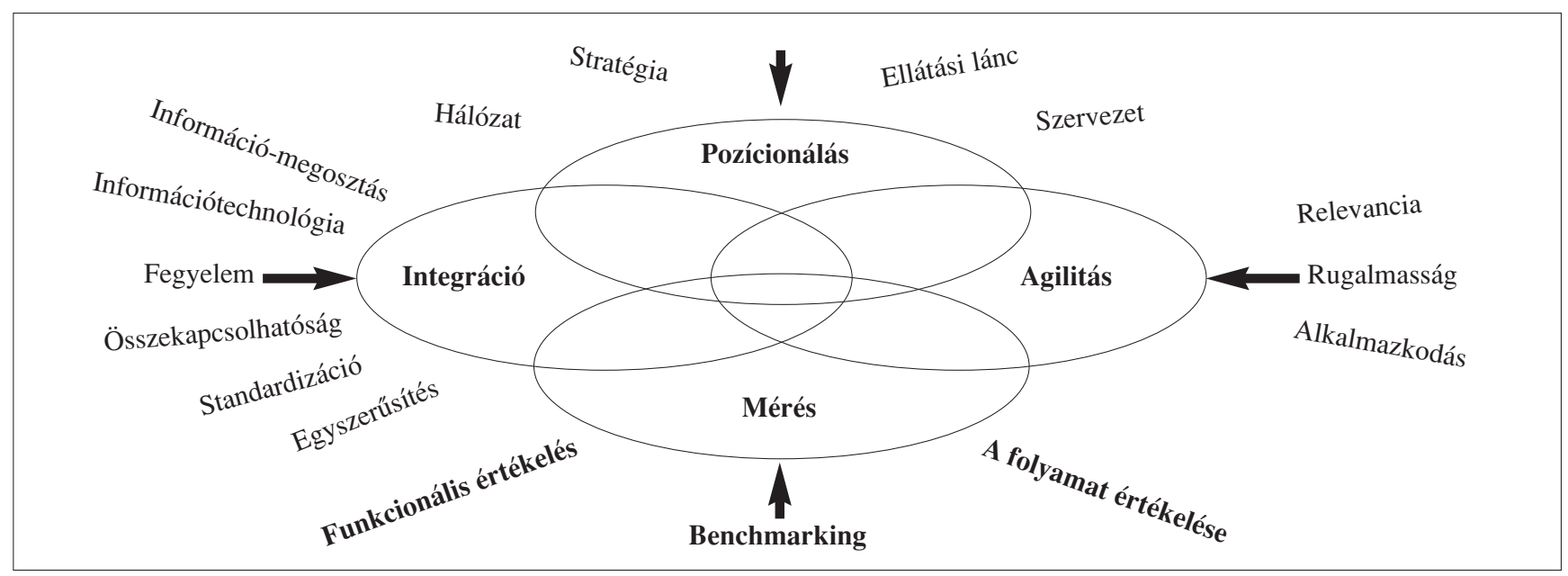

Forrás: Council of Logistics Management, 1995 
3. Agilitás. Az agilitás központi eleme a rugalmasság, a fogyasztói igények változásaira történő reagálás képessége. A kiváló logisztikával rendelkező vállalatok sokkal jobban figyeltek ezekre a változásokra, amelyek a fogyasztói igények területén történtek, mivel az, ami tegnap releváns volt, ma már nem biztos, hogy az. Ezek a vállalatok sokkal jobban alkalmazkodtak az egyedi vagy speciális igényekhez, és a váratlan igényekre is sokkal felkészültebben tudtak reagálni.

4. Teljesitménymérés. Ezen a területen három képességcsoport együttes jelenléte jellemzi a kiváló logisztikával rendelkező vállalatokat. Egyrészt a pontos és átfogó funkcionális teljesítményelemzés, másrészt a folyamatok elemzése integrált költségmenedzsment rendszerek segítségével, végül pedig a benchmarking, a vállalatok, illetve vállalati egységek összehasonlító teljesítményelemzése.

Meg kell azonban jegyezni, hogy a CLM vizsgálata során ezeket a logisztikában kiváló vállalatokat öszszehasonlították a többi vállalattal a pénzügyi eredményesség szempontjai (ROI, átlagos nyereség stb.) alapján és megállapították, hogy teljesítményeik nem kimutathatóan jobbak az átlagos vállalatokénál. Ennek oka lehet például az, hogy kevesebb figyelmet szenteltek közben a vállalat többi funkciójának fejlesztésére, de indok lehet az is, hogy sok logisztikai jellegủ beruházás csak néhány év elteltével mutatkozik meg a pénzügyi eredményességben (CLM, 1995). Összességében az a logisztikai stratégiai modell, amely a logisztikát a vállalati stratégiával összhangban a vállalati eredmények, jövedelmezőség növelése érdekében kapcsolja össze, - legalábbis rövid távon - nem érvényesül. A hazai kutatások eredményei megerősítik ezt, gyakorlatilag nem lehet szignifikáns különbséget kimutatni a kiváló logisztikával rendelkező és a logisztikát kevésbé értékelő vállalatok teljesítményei között (Gelei, 2005; Gritsch, 2001). Ugyanakkor azt gondolom, hogy a logisztika fejlesztése jó alapot szolgáltathat a jövőbeli eredményjavuláshoz. Sok esetben hiába alakítanak ki nagyon jól működő, hatékony logisztikai rendszereket, az nem mindig látszik meg rövid távon a vállalati eredményekben. Ez utóbbi állítás is felhívja a figyelmet a logisztikai teljesítmény és a vállalati teljesítmények közötti összefüggések ismeretének hiányosságaira, a kapcsolódó kutatások szükségszerűségére.

\section{Összefoglalás}

A cikkben áttekintettük a logisztikai stratégia alapvető feladatait, a vállalati logisztikai gondolkodást és stratégiaalkotást támogató legfontosabb modelleket, az irodalomban található logisztikai stratégiai típusokat és a logisztikai képességeket. Megállapítottuk, hogy a logisztikai stratégia fontos, koordináló szerepet tölt be a logisztika és a vállalati stratégiai szintek, valamint a logisztika és a többi vállalati funkcionális terület között. Megállapítottuk továbbá, hogy a porteri stratégiák logisztikai leképezésén kívül nincs általánosan, az elmélet és a gyakorlat által is elfogadott csoportosítása a logisztikai stratégiáknak.

A logisztikai képességek kulcsszerepet tölthetnek be a logisztikai és vállalati versenyképességben egyaránt. Ennek ellenére - néhány vállalati eset kivételével nincs olyan vizsgálat, ami egyértelmű kapcsolatot tudna bemutatni a logisztikai képességek és logisztikai sikeresség, valamint a vállalati versenyképesség között.

Mindezek alapján úgy gondoljuk, hogy a logisztikai stratégia általában, a gyakorlatban megfigyelhető vállalati logisztikai stratégiák, valamint a vállalati logisztikai képességek területén egyaránt további, átfogó kutatások szükségesek ahhoz, hogy a logisztika és a vállalati eredményesség közötti összefüggésekről az eddigieknél tisztább képet kaphassunk.

\section{Felhasznált irodalom}

Bowersox Donald J. - Patricia J. Daugherty (1995): Logistics Paradigms: The Impact of Information Technology, Journal of Business Logistics. No. 1. 65-80. o.

Bowersox, Donald J. - Patricia J. Daugherty (1987): Emerging Patterns of Logistical Organization; Journal of Business Logistics. No. 1. 46-60. o.

Bowersox, Donald J. - Patricia J. Daugherty (1992): Achieving and Maintaining Logistics Leadership: Logistics Organisations of the Future; Logistics Information Management, 12-17. o.

Bowersox, Donald, J. - David J. Closs (1996): Logistical Management, The Integrated Supply Chain Process; McGraw-Hill.

Cavinato, Joseph L. (1999): A general methodology for determining a fit between supply chain logistics and five stages of strategic management; International Journal of Physical Distribution and Logistics Management, No. 3. 162-180. o.

Chikán Attila (1995): A vállalatközi kapcsolatok szervezésének új formái és néhány elméleti megfontolás; kézirat

Clinton, Steven R. - David J. Closs (1997): Logistics Strategy: Does it exist?; Journal of Business Logistics. No. 1, 19-44. o.

Cooper, Martha C. - Lambert, Douglas M. - Pagh, Janus D. (1997): Supply Chain Management: More Than a New Name for Logistics; The International Journal of Logistics Management No. 1. 1-14. o.

Copacino, William - Donald B. Rosenfield (1984): Analytic tools for strategic logistics planning, IJPD \& LM, No. 3. 47-61. o.

Council of Logistics Management (1995): World Class Logistics, The Challenge of Managing Continuous Change; Michigan State University Global Logistics Research Team, Oak Brook, Il.

Gelei Andrea (1997): A logisztikai menedzsment szerepe a vállalati versenyképesség biztosításában. „Versenyben a világgal” kutatási program, Logisztika alprojekt zárótanulmánya; BKE Vállalatgazdaságtan Tanszék

Gelei Andrea (2003): Az ellátási lánc típusai és menedzsmentkérdései; Vezetéstudomány. 7-8. sz. 24-34. o.

Gelei Andrea (2005): Logisztikai képességek a magyar vállalatok gyakorlatában; Versenyképesség kutatások műhelytanulmány 
sorozat. 16. Budapesti Corvinus Egyetem, Versenyképesség Kutatóközpont

Gritsch Mátyás (2001): A logisztikai stratégia szerepe a vállalati versenyképességben: a magyar vállalatok előtt álló kihívások és lehetőségek, PhD Értekezés, BKÁE

Gritsch Mátyás (2003): Ellátásilánc-menedzsment. In. Chikán Attila - Wimmer Ágnes: Üzleti fogalomtár, Alinea Kiadó

Herter, Matthias (2000): Strategisches Management der Logistik; Shaker Verlag, Aachen.

Heskett, James L. (1977): Logistics - essential to strategy; Harvard Business Review, No. 6., 85-96. o.

Hill, Terry (1995): Manufacturing Strategy. Text and Cases; MacMillan Business

Kent, John L. Jr. - Daniel J. Flint (1997): Perspectives on the Evolution of Logistics Thought; Journal of Business Logistics, No.2.

Kummer, Sebastian (1999): Berücksichtigung der Logistik in der Unternehmensführung; In: Jürgen Weber - Helmut Baumgarten: Handbuch Logistik, Schäffer-Poeschel

Magretta, Joan (1998): The Power of Virtual Integration: An Interview With Dell Computer's Michael Dell, Harvard Business Review, March-April. 72-85 o.

McGinnis, Michael A. - Jonathan W. Kohn (1990): A Factor Analytic Study of Logistics Strategy; Journal of Business Logistics, No. 2. 41-63. o.

McGinnis, Michael A. - Jonathan W. Kohn (1993): Logistics Strategy, Organizational Environment, and Time Competitiveness; Journal of Business Logistics, No. 2. 1-23. o.

Mentzer, John T. - William DeWitt - James S. Keebler - Soonhong Min - Nancy W. Nix - Carlo D. Smith - Zach G. Zacharia (2001): Defining Supply Chain Management. Journal of Business Logistics, No. 2. 1-25. o.
O'Laughlin, Kevin A. - William C. Copacino (1994): Logistics Strategy; In. James F. Robeson - William C. Copacino: The Logistics Handbook, The Free Press

Olavarrieta, Sergio - Alexander E. Ellinger (1997): Resourcebased Theory and Strategic Logistics Research; International Journal of Physical Distribution \& Logistics Management, No. 9/10. 559-587. o.

Persson, Göran (1991): Achieving Competitiveness Through Logistics; The International Journal of Logistics Management, No. 1. 1-11 o.

Pfohl, Hans-Christian - Rudolf Large (1994): Zur Eingliederung der Logistik in die Aufbauorganisation von Unternehmen. In. Heinz Isermann (Hrsg.): Logistik. Verlag Moderne Industrie, 57-70. o.

Porter, M. E. (1980): Competitive Strategy; New York: The Free Press

Prahalad, C. K. - G. Hamel (1990): The Core Competence of the Corporation; Harvard Business Review, május-június, 79-91. o.

Rushton, Alan - Richard Saw: A Methodology for Logistics Strategy Planning, The International Journal of Logistics Management, 1/1992. p. 46-62.

Shapiro, Roy D. - James L. Heskett (1985): Logistics Strategy; West Publishing

Stock, James R. - Lambert, Douglas M. (1992): Becoming a 'world class' company with logistics service quality. International Journal of Logistics Management. No. 1. 73-80. o.

Stock, James R. - Lambert, Douglas M. (2001): Strategic Logistics Management; McGraw-Hill Irwin

Wegner, Ullrich (1996): Einführung in das Logistik-Management; Gabler

Wimmer Ágnes (2003): Outsourcing. In. Chikán Attila - Wimmer Ágnes: Üzleti fogalomtár, Alinea Kiadó

\section{E számunk szerzői:}

Dr. BOKOR Attila, egyetemi docens, Budapesti Corvinus Egyetem; Dr. RADÁCSI László, közgazdász, MTA; FILEP Judit, munkatárs, Budapest Bank ZRt.; Dr. SZIRMAI Péter, egyetemi docens, Budapesti Corvinus Egyetem; Dr. BARAKONYI Károly DSC, egyetemi tanár, PTE; Dr. GRITSCH Mátyás, egyetemi adjunktus, Budapesti Corvinus Egyetem; DÉNES Tamásné, controlling szakértő, Hungarian Interim Management; Dr. LAKI Gábor, egyetemi adjunktus, Szent István Egyetem Környezetgazdálkodási Intézet; PERÉNYI Áron, PhD hallgató, BMGE; Dr. VÉRY Zoltán, közgazdász, MCE

Előző számunk szerzői felsorolásából kimaradt Dr. KRISZTIÁN Béla, egyetemi docens, PTE, akitől ezúton is elnézést kér a Szerkesztőség. 